\title{
IODP Expedition 317: Exploring the Record of Sea-Level Change Off New Zealand
}

\author{
by Craig S. Fulthorpe, Koichi Hoyanagi, Peter Blum, \\ and IODP Expedition 317 Scientists
}

\begin{abstract}
Expedition 317 investigated the record of global sea-level change (eustasy) within continental margin sedimentary sequences and how eustasy interacts with local forcing to produce preserved sedimentary architectures. The Canterbury Basin, on the eastern margin of the South Island of New Zealand, was selected to study these complex interactions because of high rates of Neogene sediment supply from the uplifting Southern Alps. This sediment input results in a high-frequency ( 0.1-0.5 My periods) record of depositional cyclicity that is modulated by the presence of strong ocean currents. The expedition recovered sediments as old as
\end{abstract}

Eocene but focused on the sequence stratigraphy of the late Miocene to Recent, when global sea-level change was dominated by glacioeustasy. A transect of three sites was drilled on the continental shelf (Sites U1353, U1354, and U1351), plus one on the continental slope (Site U1352). The transect samples the shallow-water environment most directly affected by relative sea-level change. Lithologic boundaries, provisionally correlative with seismic sequence boundaries, have been identified in cores from each site. Continental slope Site U1352 provides a record of ocean circulation and fronts during the last $\sim 35 \mathrm{My}$. The early Oligocene ( $\sim 30 \mathrm{Ma})$ Marshall Paraconformity was the deepest target of Expedition 317 and is hypothesized to represent intensified current erosion or non-deposition associated with the initiation of thermohaline circulation in the region. Expedition 317 involved operational challenges for JOIDES Resolution, including shallow-water, continental-shelf drilling and deep penetrations. Despite these challenges, Expedition 317 set a number of records for scientific ocean drilling penetration and water-depth.

\section{Introduction and Goals}

In order to evaluate predictions of future changes in global sea level and shoreline location, it is vital to constrain the range of past variability. Throughout the "Icehouse" period of the last $\sim 30-40$ million years, the changing volume of continental ice has been the principal driver of high-amplitude and high-frequency ( 1 My and less) global sea-level change (eustasy). The last $\sim 1$ million years have been dominated by 100,000-year glacial/interglacial cycles, and the sea-level rise since the last glacial maximum provides particularly valuable constraints on potential future rates of rise. However, earlier periods-notably the early Pliocene $(\sim 5.3-3.0 \mathrm{Ma})$ when $\mathrm{CO}_{2}$ levels were similar to today's, but temperatures were $\sim 3^{\circ} \mathrm{C}$ warmer and sea level $\sim 25 \mathrm{~m}$ higher-provide glimpses of the possible future state of the Earth system. In addition, the geological record shows that climate and sea level do not always 
respond linearly to forcing and that abrupt events can disrupt gradual trends. If we are to develop reliable predictions of future climate and sea levels, we must look to the geologic record to ensure that the models on which we base forecasts can also reproduce the past.

Continental margin sediments retain long records of global sea-level change. This stratigraphic record comprises stacked sedimentary units (sequences) separated by unconformities. Sequence stratigraphy highlights the cyclic nature of the continental margin record (Mitchum et al., 1977; Vail et al., 1991) and has led to the theory of eustatic control of sequences and the resultant eustatic cycle chart (Haq et al., 1987). However, basin subsidence, changes in the rate of sediment supply, and other local processes can superimpose their signatures on this record. Therefore, the application of sequence stratigraphy to sea-level studies has been contentious, largely because of uncertainty surrounding the complex interaction of global and local processes (Carter, 1985; Karner, 1986; Carter et al., 1991; Christie-Blick, 1991; Miall and Miall, 2001). Understanding

how these processes interact to form preserved stratigraphy is a fundamental problem in sedimentary geology. Its solution will yield both a record of eustatic change and a greatly enhanced ability to read the record, covering many tens of millions of years of Earth history, beneath the world's continental shelves.

Scientific ocean drilling of globally coordinated borehole transects across continental margins provides the best way to distinguish local effects and extract the sea-level signal. Such drilling targets the geological environment directly affected by sea-level change as the shoreline migrates back and forth across the continental shelf. Coring the resulting sequence stratigraphic record provides information on ages, depositional environment, and past water depths during sea-level cycles from coastal plain to continental slope settings. Since boreholes provide information at only a few locations, integration with seismic imaging is crucial. Such integration performs three vital functions: 1) placing drilling results within a two- and three-dimensional context, 2) constraining the influence on sequence architecture of along-margin changes in sediment input and basin morphology, and 3) providing paleogeomorphological constraints on sedimentary processes and paleoenvironments.

Expedition 317 applied this approach in the offshore Canterbury Basin, on the eastern margin of the South Island of New Zealand (Figs. 1-3), where high rates of Neogene sediment supply preserved a high-frequency (0.1-0.5 My periods) seismically resolvable record of depositional cyclicity (Fulthorpe et al., 2011). The transect strategy was first applied and has been most thoroughly tested on the New Jersey Mid-Atlantic Transect (MAT) by ODP Legs 150, 150X, 174A, and 174AX. Most recently, IODP Expedition 313 used a mission-specific platform to drill on the New Jersey continental shelf (Mountain et al., 2010). Prior to Expedition 317, only ODP Leg 174A (Austin et al., 1998) had employed the JOIDES Resolution to drill shelf sites for sequence stratigraphic and sea-level objectives. Expedition 317, therefore, provided a rare opportunity to investigate the facies, paleoenvironments, and depositional processes associated with the sequence stratigraphic model on a prograding continental margin where large-scale depositional geometries and sequence architectures are well constrained by seismic data. Canterbury Basin complements MAT because the Middle Miocene to Recent Canterbury sequences are mainly younger than those calibrated so far on the New Jersey margin (Fig. 4). Furthermore, in line with the global approach to sea-level change advocated by previous planning groups, the Canterbury Basin allows expanded study of complex processes of sequence formation because of the following two reasons.

1) The stratigraphy records the development of the Antarctic Circumpolar Current and related southern oceanographic fronts (Fig. 1). Currents have strongly 
influenced deposition, modifying sequence architecture and locally leading to the deposition of large sediment drifts, which aggraded to near shelf depths, within the prograding Neogene section.

2) Rifting is younger (Cretaceous) than the New Jersey margin (Jurassic), and from the earliest Miocene copious terrigenous sediment was supplied from a rapidly uplifting, nearby mountain range (the Southern Alps). Regional tectonic and geological histories have been intensively studied, allowing evaluation of the influence of sediment supply on sequence formation and of the tectonic evolution of the Alpine Fault plate boundary.

The principal scientific objective of Expedition 317 was to date clinoformal seismic sequence boundaries and sample associated facies to provide information (e.g., paleo-water depths, porosities) necessary for estimation of eustatic amplitudes using backstripping. A proper test of sequence stratigraphy necessitates drilling in shallow water $(\sim 100 \mathrm{~m}$ or less) on continental shelves. A related objective was to understand the interplay of along-strike and downslope sedimentary processes on this strongly current-influenced margin. Accordingly, our deepest drilling target was the Marshall Paraconformity, a regional unconformity thought to represent the mid-Oligocene initiation of ocean circulation on this margin. The final objective was to expand our knowledge of the erosion history of the Southern Alps using

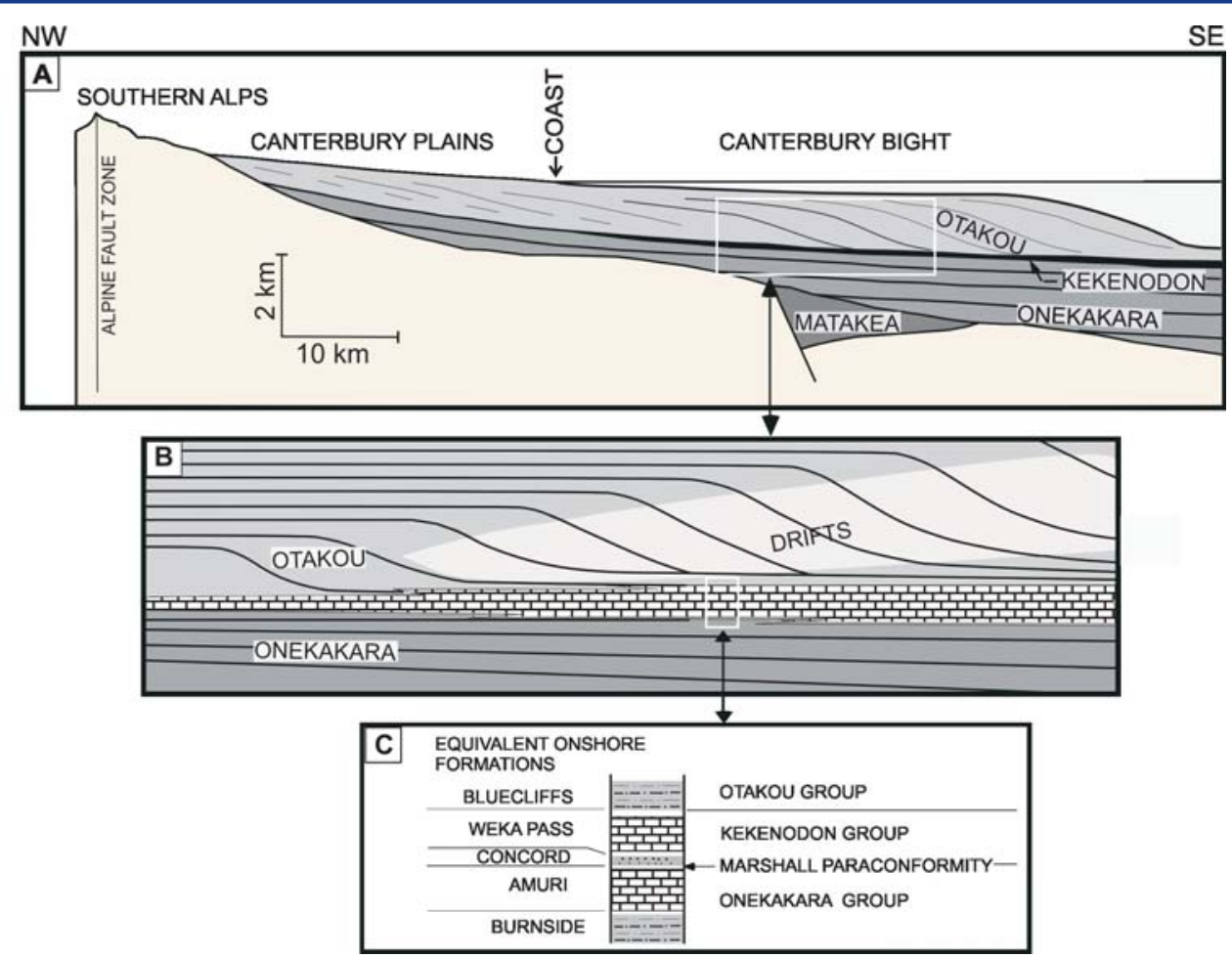

Figure 3. Schematic stratigraphy of the Canterbury Basin at three different scales. [A] Large-scale, post-rift stratigraphy (see profile location in Fig. 1). Onekakara, Kekenodon, and Otakou groups were deposited during regional transgressive, highstand, and regressive phases, respectively. [B] Seismic-scale stratigraphy. Sediment drifts occur within the Otakou Group. [C] Outcrop-scale stratigraphy across the Marshall Paraconformity. Modified from Fulthorpe et al. (1996). provenance studies and offshore sediment accumulation rates.

The Canterbury Basin is part of the Eastern New Zealand Oceanic Sedimentary System (ENZOSS; Carter et al., 1996). The distal (up to $4460 \mathrm{~m}$ water depth) component of ENZOSS was targeted by ODP Leg 181, which focused on drift development in the Southwest Pacific Gateway, principally under the influence of the evolving Antarctic Circumpolar Current and the Deep Western Boundary Current (Shipboard Scientific Party, 1999). Expedition 317 complements Leg 181 drilling by focusing on the landward part of ENZOSS.

\section{Geological Setting}

The eastern margin of the South Island of New Zealand is part of a continental fragment, the New Zealand Plateau, that rifted from Antarctica beginning at $\sim 80 \mathrm{Ma}$ (Anomaly 33). The Canterbury Basin lies at the landward edge of the rifted continental fragment and underlies the present-day onshore Canterbury Plains and offshore continental shelf (Fig. 1; Field and Browne, 1989). The plate tectonic history of the New Zealand Plateau is recorded in the stratigraphy of the South Island. The post-rift, Cretaceous to Recent sedimentary history of the Canterbury Basin comprises a first-order (80 My), tectonically-controlled, transgressive-regressive cycle (Fig. 3; Carter and Norris, 1976; Field and Browne, 1989).

The post-rift transgressive phase terminated during the late Eocene, when flooding of the land mass was at a maximum (Fleming, 1962). Reduced terrigenous influx resulted in deposition of regionally widespread pelagic limestone (Amuri Limestone), which ranges in age up to early Oligocene ( 33 Ma). The sequence is then interrupted by the Marshall Paraconformity (Fig. 3; Carter and Landis, 1972). The paraconformity is recognized at drill sites throughout the region east of the Tasmanian gateway and is hypothesized to represent the initiation of thermohaline circulation upon opening of the seaway between Antarctica and Australia ( 33.7 Ma; Carter et al., 2004). New Zealand lay directly in the path of 
the developing current system. Regression commenced in the late Oligocene or early Miocene in response to an increase in sediment supply provided by the initiation of Alpine Fault movement (Carter and Norris, 1976; Kamp, 1987). The Alpine Fault formed as a dextral transpressive zone with $500-\mathrm{km}$ lateral displacement since the earliest Miocene ( 23 Ma; Wellman, 1971; Kamp, 1987; King, 2000). The sediment influx following fault initiation is distinct from the later pulse related to uplift that culminated in the present-day Southern Alps. Uplift of the Southern Alps accelerated at $\sim 8-5 \mathrm{Ma}$ (Tippett and Kamp, 1993a; Batt et al., 2000) or $\sim 10-8$ Ma (Carter and Norris, 1976; Norris et al., 1978; Adams, 1979; Tippett and Kamp, 1993b), indicating an increased component of convergence along the fault and leading to further increase in the rate of sediment supply to the offshore Canterbury Basin (Lu et al., 2005).

This sediment influx was deposited as prograding clinoforms (Otakou Group; Fig. 3). However, currents continued to influence deposition. At present, the core of the northward-flowing Southland Current, inboard of the Southland Front (part of the Subtropical Front; STF) is over the $\sim 300$-m isobath (Chiswell, 1996).

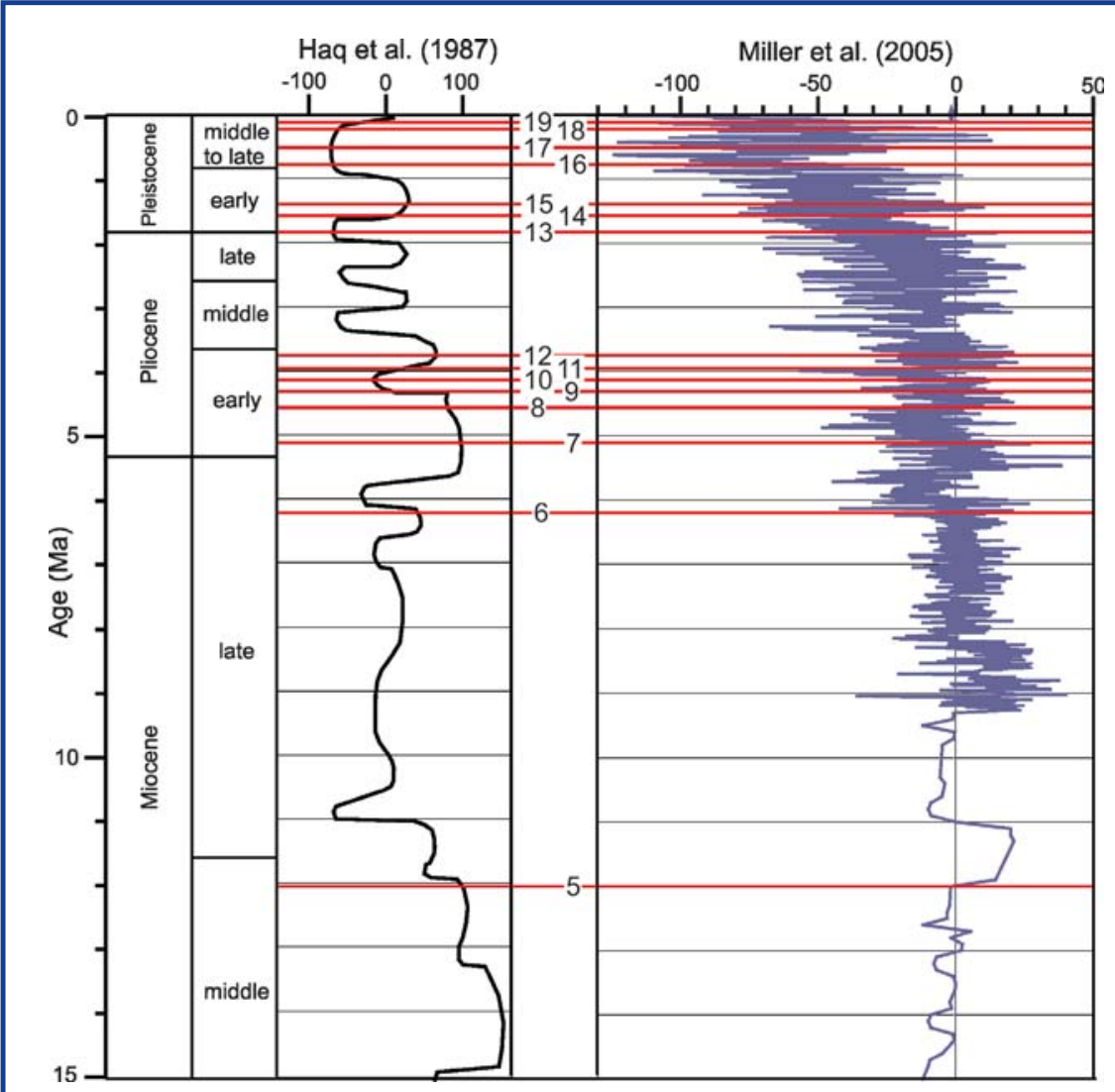

Figure 4. Global sea-level curves of Haq et al. (1987) and Miller et al. (2005) from the middle Miocene to Recent. Unconformities U5 to U19 are labeled and shown as red lines (shipboard ages are approximate). Note that much of the upper part of the Pliocene section is missing at Expedition 317 sites and a 5-My hiatus occurs in the upper Miocene, accounting for the large time gaps between some unconformities. Prior to $9 \mathrm{Ma}$, the Miller et al. (2005) curve is derived from backstripping of New Jersey MAT sites. However, the record since $9 \mathrm{Ma}$ is a benthic foraminiferal $\delta^{18} \mathrm{O}$ record, calibrated to represent eustasy, because the MAT record there is incomplete.
In deeper water, to at least $900 \mathrm{~m}$, a local gyre of the Antarctic Circumpolar Current circulates clockwise within the head of Bounty Trough parallel to the Southland Current (Fig. 1; Morris et al., 2001). Large sediment drifts within the prograding section (Fig. 5) show that similar currents, probably strengthened during glacial periods, existed throughout much of the Neogene (Fulthorpe and Carter, 1991; Lu et al., 2003; Carter et al., 2004).

\section{Drilling and Coring}

Expedition 317 cored upper Miocene to Recent sedimentary sequences in a transect of three sites on the continental shelf (landward to basinward: Sites U1353, U1354, and U1351) and one on the continental slope (Site U1352; Fulthorpe et al., 2011). A transect of sites is required because of the need to drill each of the multiple target sequences in at least two locations: 1) landward of clinoform breaks or rollovers, presumed to represent paleo-shelf edges, where paleo-depth indicators are most reliable; and 2) drilling on the slope where increased abundance of pelagic microfossils provides the best age control.

Favorable weather conditions on arrival allowed us to follow the planned drilling strategy by drilling first at shelf
Site U1351 at the deep-water end $(121 \mathrm{~m})$ of the shelf transect (Figs. 2, 6). This provided experience in shelf sediment drilling before moving to sites in even shallower water. The ship then moved $\sim 15 \mathrm{~km}$ to slope site U1352, designed to provide age control for sequences drilled at site U1351 (Figs. 2, 7). An additional target at Site U1352 was penetration and recovery of the Marshall Paraconformity. On completion of slope drilling, the ship moved back to the shelf to drill the two additional shelf sites U1353 and U1354 (Fig. 6) to provide spatial control of facies within sequences and to recover the lowermost unconformities landward of their rollovers.

Because of the requirements to drill in shallow water and to achieve deep penetrations, a number of scientific ocean drilling records were set.

- Deepest hole drilled in a single expedition (Hole U1352C; $1927 \mathrm{~m}$ ), also the second deepest hole in DSDP/ODP/IODP history

- Deepest hole drilled by JOIDES Resolution on the continental shelf (Hole 1351B; $1030 \mathrm{~m}$ ) and also the second deepest (Hole 1353B; $614 \mathrm{~m}$ ) 


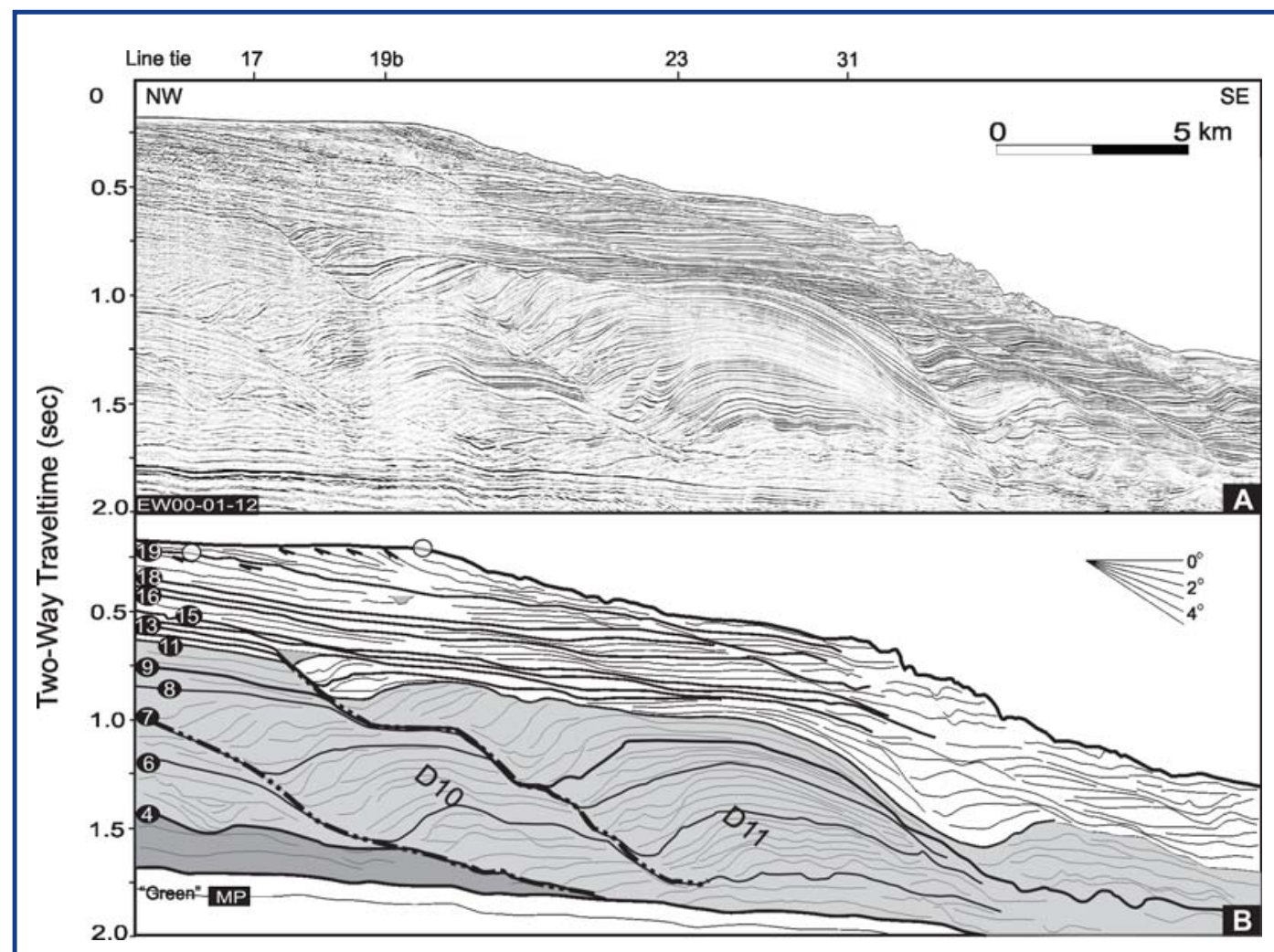

Figure 5. [A] Uninterpreted dip profile EW00-01-12 across the slope in the northern part of the survey grid showing mounded sediment drifts with adjacent (landward) moats (see Fig. 2 for location). [B] Interpretation showing sequence boundaries and selected locations of reflection truncation (arrows). Drifts D10 and D11 are the last of the succession of large elongate drifts of the Canterbury Basin (Fig. 2). Drifts migrate northwestward (landward) on dip profiles. Erosional unconformities at the landward edges of drift moats are diachronous, and they are intersected by multiple sequence boundaries. The underlying Marshall Paraconformity (MP) is also shown.

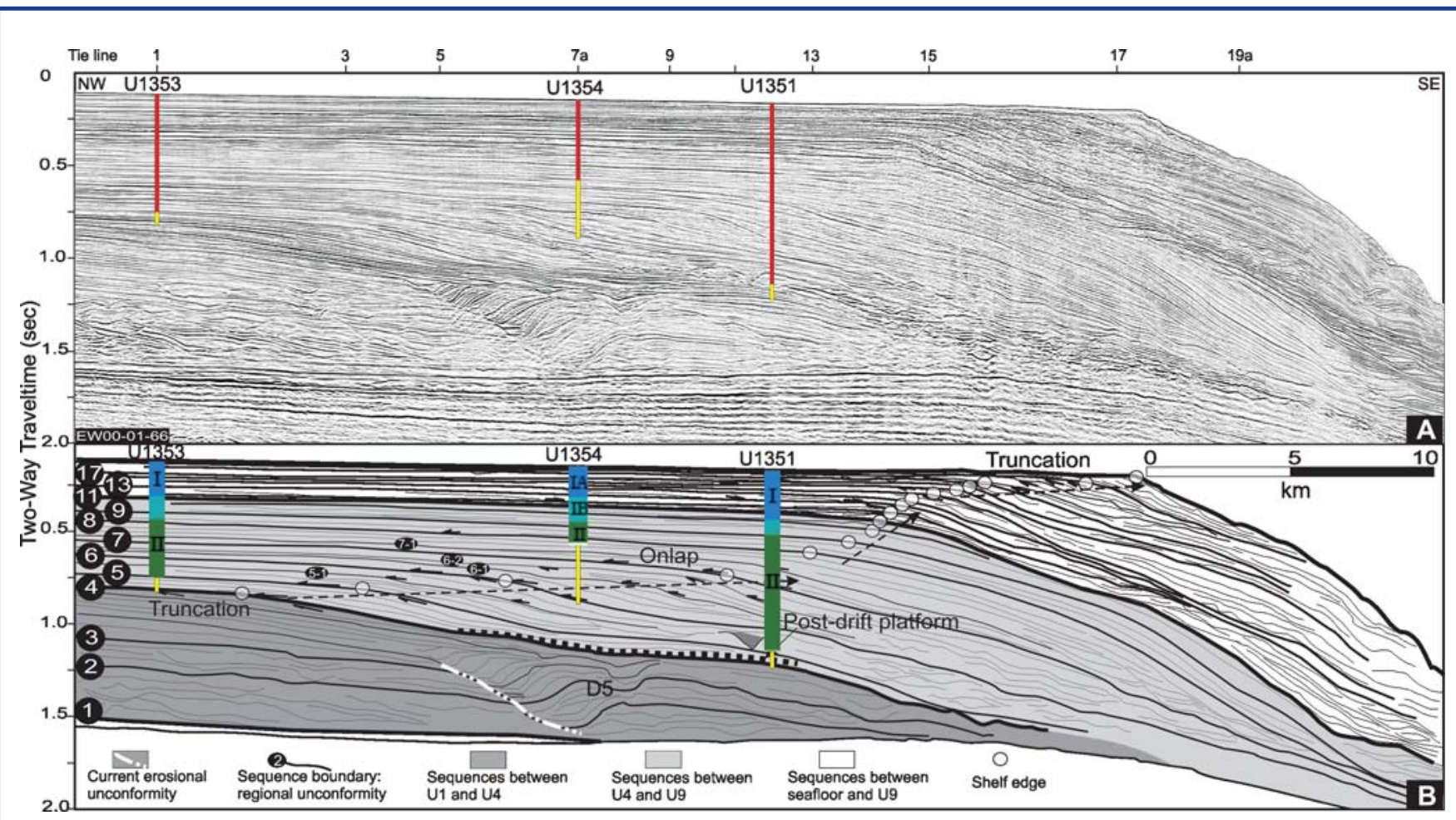

Figure 6. [A] Uninterpreted MCS dip profile EW00-01-66 from the southern part of the survey grid showing locations of sites U1351, U1353, and U1354. Actual penetrations shown in red, proposed penetrations in yellow (see Fig. 2 for location). [B] Interpretation showing sequence boundaries and selected locations of onlap, truncation, and downlap (arrows). Lithostratigraphic units defined at shelf Sites U1353, U1354, and U1351 are also shown. Clinoform rollovers, or breaks, representing paleoshelf edges, are marked by circles. Paleoshelf edges from U4 to U8 prograde steadily. The amount of progradation decreases from U8 to U12, increasing again from U13 to U19. U4-U10 are onlapped and truncate underlying reflections; internal reflection geometries from U4 to U10 are mainly sigmoidal. In contrast, U11-U19 are downlapped on paleoshelves, but also truncate underlying reflections, and internal reflection geometries from U11 to seafloor are oblique. Site U1351 sampled paleoslopes of U6-U7 and sampled U8-U19 landward of their paleoshelf edges. Sites U1353 and U1354 sampled sequence boundaries from U5 to U18 landward of their paleoshelf edges in more proximal settings. Sediment drift development in this area had largely ceased by U4; only drift D5 is present. Prograding clinoforms dominate later sequences. 
- Shallowest water depth for a site drilled by JOIDES Resolution for scientific purposes (Site U1353, $84.7 \mathrm{~m}$ water depth)

- Deepest sample taken by scientific ocean drilling for microbiological studies (1925 m at Site U1352)

\section{Sequence Stratigraphy and Sea-Level Change}

Seismic sequence boundaries provide the large-scale understanding of subsurface architecture necessary for placing drilling results within a broader two- and three-dimensional context. The seismic stratigraphy of the Canterbury Basin was developed using high-resolution $(\sim 5$-m vertical resolution for two-way traveltimes $<1$ second) multichannel seismic (MCS) profile collected by R/V Maurice Ewing in 2000 (EW00-01 profiles; Figs. 2, 5, 6, 7). These were augmented by commercial MCS data collected in 1982 (Fig. 2; CB-82 profiles).

Nineteen regional seismic sequence boundaries (U1-U19) are identified in the middle Miocene to Recent shelf-slope sediment prism (Fig. 4; Lu and Fulthorpe, 2004). Expedition 317 provides ground truth for sequences above U5. Two larger seismic units are defined, based on seismic architecture and facies, within the cored interval (Fig. 6).

1. U5-U10 feature rounded shelf-slope rollovers. Internal reflection geometries are predominantly sigmoid, and paleoshelves are smooth and defined by onlap and truncation.

2. U11-U19 are downlapped on paleoshelves. They truncate underlying reflections near paleoshelf edges, which tend to be angular. Internal reflection geome- tries are oblique and $\mathrm{U}$ - and $\mathrm{V}$-shaped channels that incise paleoshelves indicate exposure during sea-level lowstands.

The influence of sea-level change is illustrated at several scales. At the largest scale, the boundaries between Lithostratigraphic Units I and II at shelf sites separate overlying heterolithic facies of Unit I from more uniform facies below in Unit II (Figs. 6, 7). Unit I contains a wide variety of facies and many green marl or calcareous beds with sharp (or bioturbated) bases. On the shelf, the more homogeneous Unit II is dominated by mud or muddy sand, with lower percentages of carbonate components and less frequent greenish calcareous beds, whereas on the slope this unit is represented by homogeneous sandy marlstone.

The location of the unit boundary is difficult to identify precisely because the transition between units is gradational and also because of low recovery near some unit boundaries. However, the Unit I to Unit II boundary generally conforms to the interval around the predicted depths of seismic sequence boundaries U10 to U12 (late Pliocene), in a zone where high-amplitude seismic reflections related to clinoforms with angular shelf-slope rollovers transition downward to clinoforms with rounded rollovers (Fig. 6). The lithological contrast between Units I and II and the contrasting characteristics of sequence boundaries and seismic facies above and below U10 are inferred to occur because paleoshelves of U10 and underlying sequence boundaries were not subaerially exposed at lowstand, whereas those above U10, were exposed, probably because of increasing eustatic amplitudes during the Pleistocene.

At a finer scale, correlation of specific lithological features with seismic sequence boundaries is also possible. Erosion surfaces with associated overlying sediment facies were

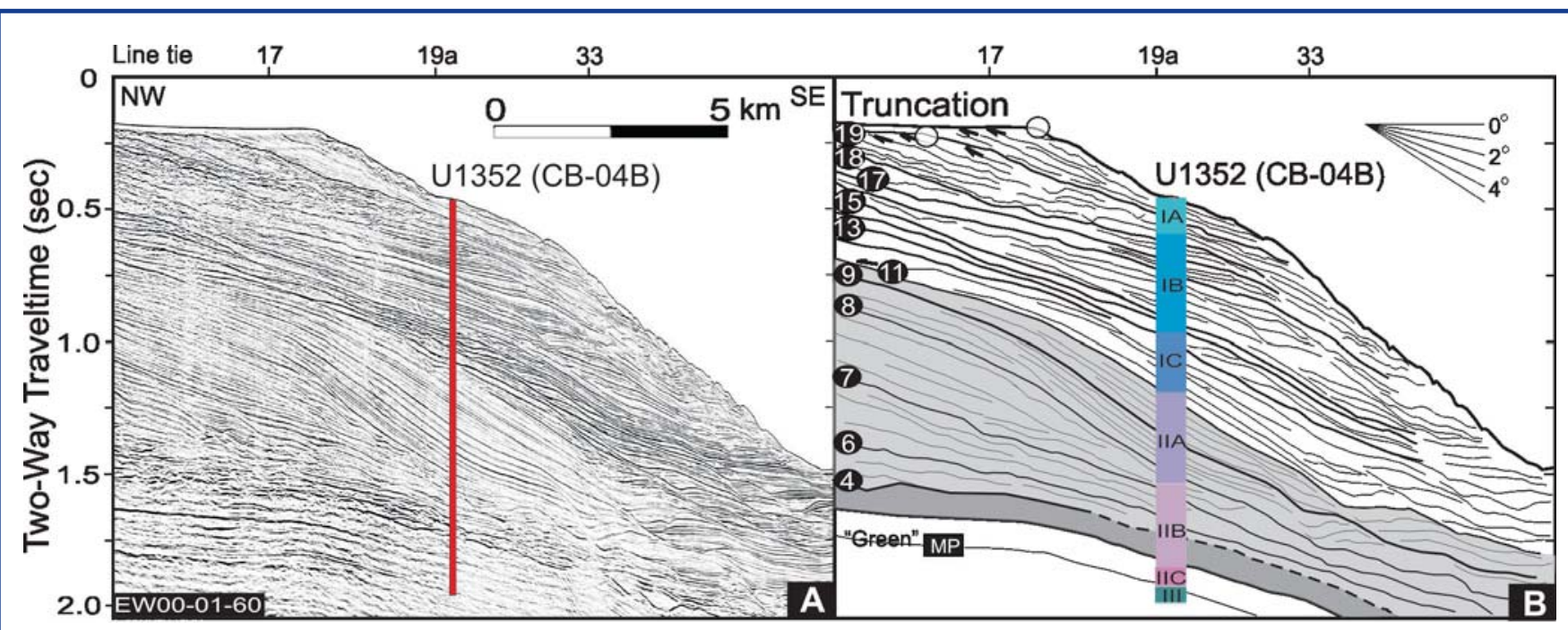

Figure 7. [A] Uninterpreted dip profile EW00-01-60 across the slope in the southern part of the survey grid showing location of Site U1352 (see Fig. 2 for location). [B] Interpretation showing sequence boundaries and selected locations of reflection truncation (arrows). Lithostratigraphic units are also shown. Site U1352 sampled slope facies of sequences, particularly important for age control, as well as the underlying Marshall Paraconformity (MP). 
identified near the predicted depths of seismic sequence boundaries at all sites (Fig. 8). Identification is based on changes in lithologic composition, presence of transported sediments, and the nature of the contacts. When basal erosion surfaces were not recovered, surfaces may be inferred from the presence of sand-or the assumption of washed-out sands-and correlation to wireline logs. These lithologic surfaces and associated sediments are believed to be correlative between sites across the transect.

Candidate sequence boundaries are best identified in Lithostratigraphic Unit I at each site, where recovery was highest and where lithologic contrasts are most pronounced. Unit I erosion surfaces have been correlated with seismic sequence boundaries U19-U11 and, at Site U1351, are overlain by a series of lithofacies associations comprising upward-fining shelly sandy mud topped by coarseningupward sandy mud (Figs. 8, 9). Together, the package is provisionally interpreted as a transgressive, wave-eroded ravinement surface overlain by a lag deposit corresponding to a transgressive systems tract. Subsequent highstand mud units are topped by the regressive, coarsening-upward sediments (Type 2 facies assemblage; Fig. 9). The facies assemblage includes decimeter- to centimeter-thick clay beds similar to those attributed to rapid deposition by flood events on modern shelves near sediment-rich fluvial systems. Truncated versions of this facies association, lacking the

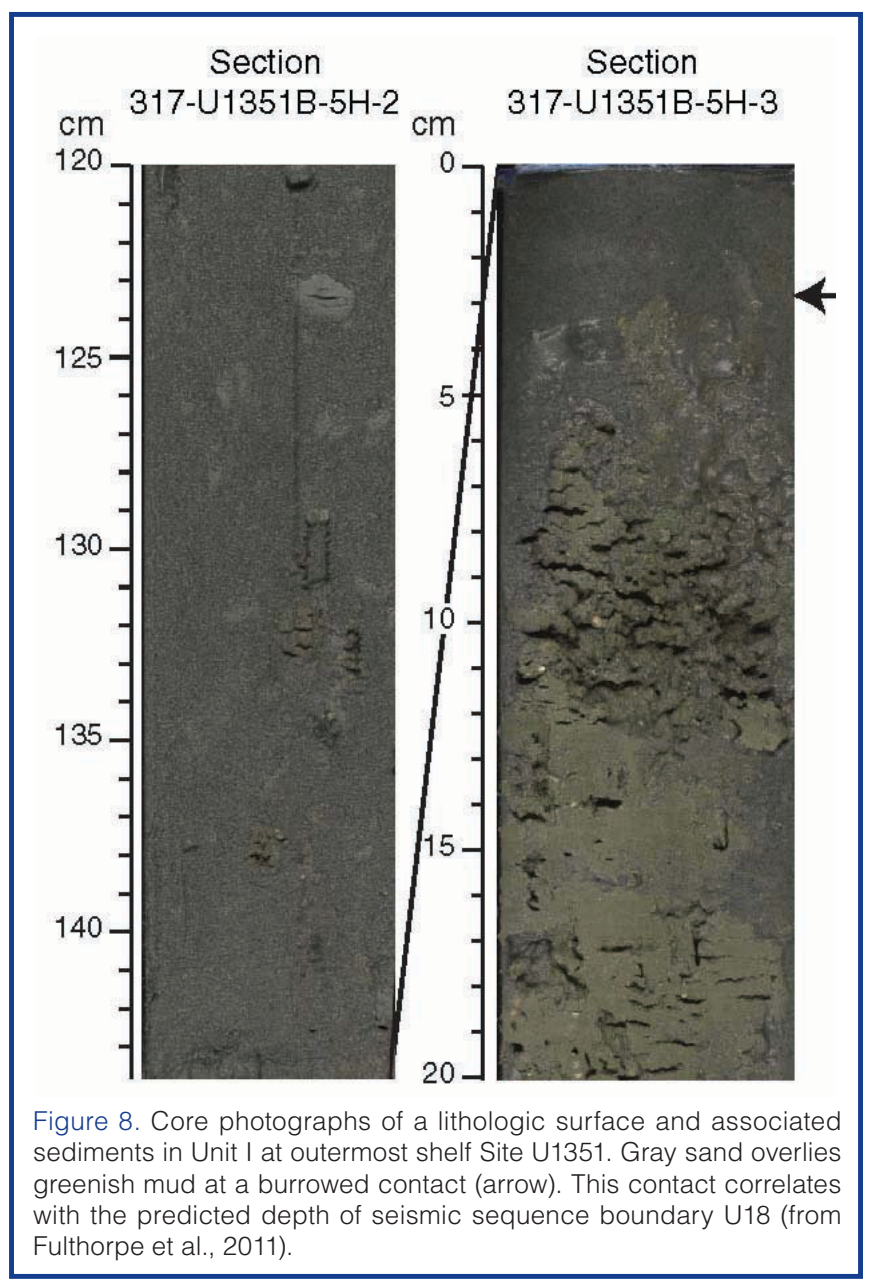

regressive highstand phase, occur in the upper $30 \mathrm{~m}$ at Site U1352, suggesting more frequent erosive episodes (Type 1 facies assemblage; Fig. 9). There are more such truncated facies associations than there are seismic sequence boundaries, and it is therefore possible that some of the truncated facies associations may represent higher-order cycles or autocyclicity. The facies associations, both complete and truncated, are similar to those known from the Wanganui Basin (Abbott and Carter, 1999; Saul et al., 1999; Abbott et al., 2005; Naish et al., 2005).

Erosion surfaces have not been identified in Unit II, which is more homogeneous and where recovery beneath the shelf was poorest. However, indurated intervals of in situ carbonate cementation may correlate with seismic sequence boundaries. Sediment recovered from Unit II was predominantly muddy, suggesting deposition on a shelf below fair-weather wave base. The lack of abundant shell debris suggests that the setting was more distal than during deposition of Unit I.

Fitting seismically resolvable sequences within the hierarchy of known global forcing has long been problematic. The relationship between high-frequency Milankovitch cycles and longer, seismic-scale sequences remains an unresolved area of research. Saul et al. (1999) showed that, for the Wanganui Basin, classic fourth- and fifth-order cyclothems are grouped together into third-order cycles that were controlled by basin-wide tectonic rhythms. Alternatively, Miller et al. (2005) have pointed out that some third-order cyclicity may be manifestations of longer wavelength Milankovitch periodicities of 1.2 My and 2.4 My, or of interference between these cycles.

The high accumulation rates of the Canterbury Basin provide the opportunity to link seismic sequences to specific Milankovitch frequencies, as revealed by oxygen isotopic records (Fig. 4). This will allow us to evaluate how predominant forcing frequencies change through time and to constrain the depositional parameters required to generate and preserve seismically resolvable sequences. The seismic sequences span the range between Milankovitch-scale cyclicity and longer period, third-order, seismically resolvable cycles. The two upper, seismically delimited sequences beneath the shelf (corresponding to the sequences overlying seismic sequence boundaries U18 and U19) almost certainly represent 100-k.y. cycles corresponding to marine isotope stages (MIS) 1-5 and 6-7, respectively, based on magnetic susceptibility and natural gamma ray time series. Correlations with older MIS stages are also likely as ages are refined. In contrast, Miocene to early Pliocene sequences represent longer cycles and may correlate with the 400-k.y. eccentricity cycle.

\section{Influence of Ocean Currents on Deposition}

Northeastward flowing currents (Southland Current, inboard of the Subtropical Front, and a gyre of the 
Subantarctic Front) sweep the margin today to water depths of $\sim 900 \mathrm{~m}$ (Chiswell, 1996; Morris et al., 2001; Fig. 2). The buried sediment drifts in the Canterbury Bight, as well as outcrop evidence of current-related deposition, suggest that similar currents have been active for the last $30 \mathrm{My}$ (Fig. 5). However, the influence of currents on deposition at seismic scale varies markedly along strike, with large drifts developing in the northeast near ODP Site 1119 (Leg 181), while coeval sequences to the southwest at the Expedition 317 transect are clinoformal (compare Figs. 5 and 6). The role of alongstrike processes in sequence stratigraphy has been unclear; sediment transport in the sequence stratigraphic model is viewed as essentially two-dimensional. Expedition 317 results provide insight into the interaction of along-strike and downslope processes within a sequence stratigraphic framework in a location where a current is known to have been present, but whose seismic stratigraphic signature varies greatly both spatially and temporally.

Beginning at the seafloor, ODP Site 1119 sediments are interpreted as products of current reworking, corresponding to the clear seismic signatures of sediment drift development. In contrast, Site U1352 features a complex interplay of along-strike and downslope depositional processes. For example, the uppermost interval (Subunit IA; 0-98 m, Pleistocene to Holocene) is interpreted as a series of lowstand shelf-edge deltas fed by sediment gravity flows represented by sharp-based gray very fine to fine sands, whose mineralogy indicates direct offshore and downslope transport from sources in the Torlesse Terrane, located onshore adjacent to the drilling area. This interpretation is supported by the presence of reworked nannofossils consisting of mixed, poorly-preserved Eocene-Oligocene assemblages derived from onshore. However, the rest of Site U1352 (Subunit IB and below) and the slope interval of Site U1351 include sediment from the Otago Schist to the south, indicating increasing downhole importance of along-strike transport. Nevertheless, downslope transport is also interpreted in Subunit IB. Interbedded, sharp-based greenish sands that occur within dark gray hemipelagic mud are interpreted as mass flows; abundant shells in one sand suggest transport from a shallow marine environment. Therefore, Subunit IB is a transitional interval of increasing (downhole) contourite deposition culminating in Subunit IC, which contains a well-sorted, very fine-grained sand fraction consistent with considerable transport distance. Subunit IC also contains reworked nannofossils. However, in contrast to those in Subunit IA, these reworked assemblages are well-preserved and contain cold-water taxa from a monospe- cific age consistent with an along-strike source. This interpretation is more consistent with that of the coeval interval at Site 1119. Hemipelagic sediments of Units IIA and IIB at Site U1352 may have been deposited as sediment drifts; subtle seismic geometries suggest the influence of along-strike processes (e.g., paleoslopes on Figs. 6 and 7). Diagnostic sedimentary structures are rare, partly because of extensive bioturbation, but intermittent wavy laminations occur in Unit IIB. Alternations of light-colored marlstone with darker mud-stone may reflect switching between hemipelagic carbonate deposition and increased terrigenous influx corresponding to alternating along-strike and downslope sedimentary processes, respectively. Expedition 317 drilling therefore provides insights into the development of ocean circulation in this region, as well as the interaction of along-strike and downslope processes with implications for both sequence stratigraphy and models of clinoform development.

\section{Marshall Paraconformity}

The Marshall Paraconformity is a regional unconformity terminating the post-rift transgressive phase and capping the widespread Amuri Limestone formation. The paraconformity has been dated at its onshore type section using strontium isotopes as representing a minimum hiatus of 
32.4-29 Ma (Fulthorpe et al., 1996). There, it is overlain by mid-late Oligocene cross-bedded glauconitic sand (Concord Formation) and calcarenite limestone (Weka Pass Formation). The paraconformity was the deepest target of Expedition 317 drilling and is hypothesized to represent intensified current erosion or non-deposition associated with the initiation of thermohaline circulation upon opening of the seaway between Antarctica and Australia ( 33.7 Ma), prior to opening of the Drake passage (Carter, 1985; Fulthorpe et al., 1996; Carter et al., 2004).

The Marshall Paraconformity was represented by a lithologic change at $1853 \mathrm{~m}$ in Hole 1352B (Fig. 10). The paraconformity marks the boundary between overlying lower Miocene glauconitic limestone and underlying lower Oligocene recrystallized pelagic nannofossil limestone containing trace fossils and stylolites, equivalent to the onshore Amuri Limestone. Recovery was low across the paraconformity, which was represented by a decimeter-scale rubble zone in recovered core. No equivalent to the Concord Formation glauconitic sand was recovered, although logs from nearby Clipper-1 exploration well (Fig. 2) suggest that a boundary sand layer is present. One possibility is that sediment loading caused the Concord-Formation-equivalent greensand to be injected into the overlying sandy marlstones and limestones to produce distinctive glauconitic sand layers (Fig. 10). The hiatus at the paraconformity is estimated to be 11-12 My at Site U1352, conforming with previous observations that the hiatus is longer offshore than at the type section, perhaps owing to greater current-induced erosion at such deeper-water locations (Shipboard Scientific Party, 1999; Carter et al., 2004). Hole 1352B terminated in upper Eocene (35.2-36.6 Ma) limestone.

\section{The Future: a Global Array of Sea-Level Transects}

The study of global sea-level change requires a global approach. Worldwide correlation is essential to establish the degree to which sequence boundaries are synchronous and to confirm that eustatic amplitude estimates from individual margins are globally consistent. The Canterbury Basin is therefore one element in a worldwide array of scientific ocean drilling transects, some of which have been drilled while others remain in the proposal stage. New Jersey MAT drilling on the coastal plain, shelf, and slope has already yielded a record of global sea-level timing and amplitudes since the Late Cretaceous (Fig. 4; Miller et al., 2005; Kominz et al., 2008). Such records are derived using one- and two-dimensional backstripping, requiring as inputs sequence-boundary ages, paleobathymetry from benthic microfossils, porosity profiles (for decompaction calculations), and tectonic history. Drilling for long-term sea-level objectives has also been carried out in the Bahamas and on the Marion Plateau (ODP Legs 166 and 194, respectively).
Expedition 317 was designed using the strategy developed for MAT. We are following a parallel approach in refining Expedition 317 results with the ultimate goal of producing a late Miocene-Recent eustatic record for correlation both with MAT results and with the oxygen isotopic record of global climatic variation. Additional transects are required to cover both Greenhouse and Icehouse records. This approach will necessitate integration of onshore and offshore drilling and use of Mission Specific Platforms in

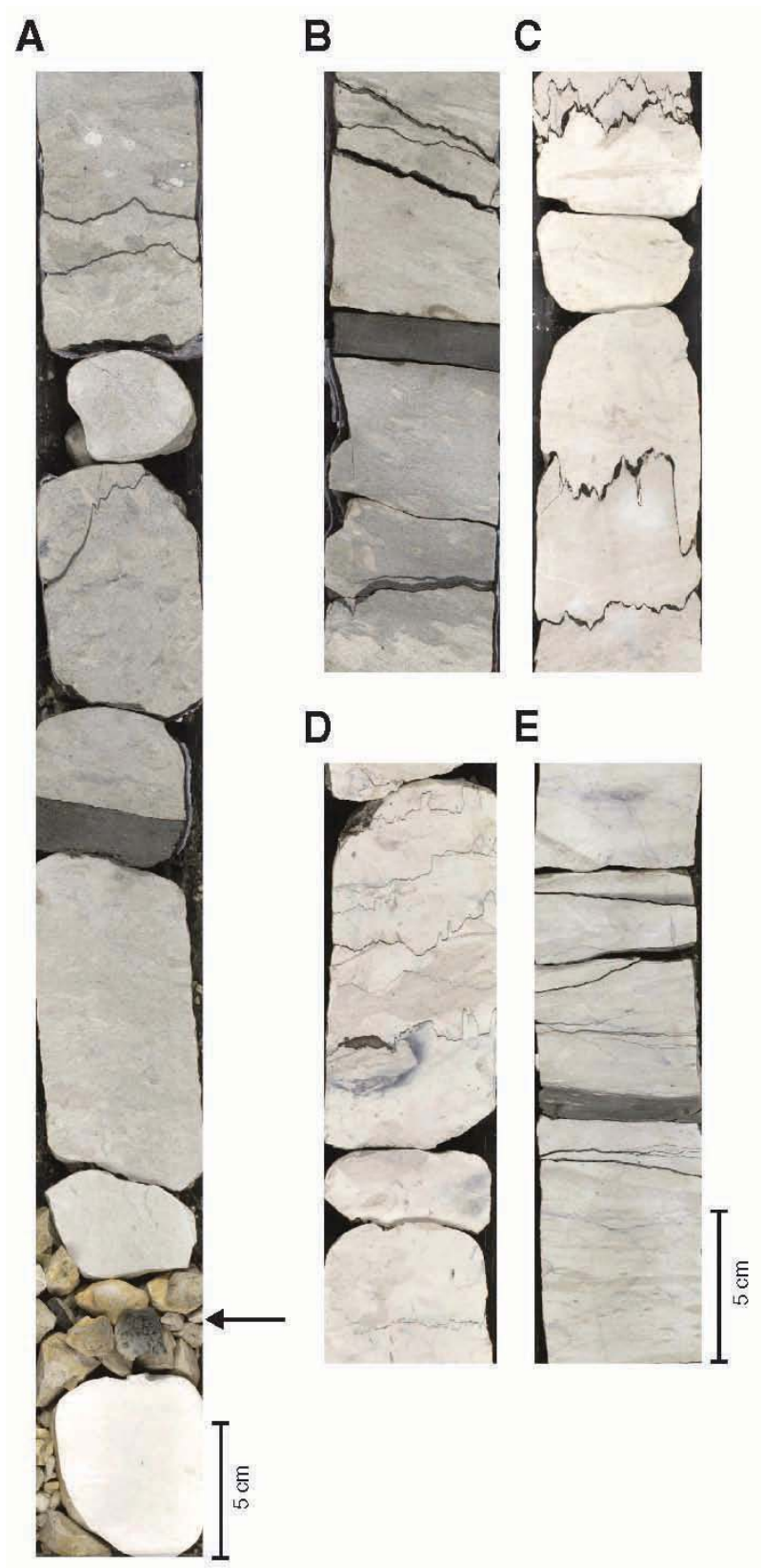

Figure 10. [A] Marshall Paraconformity (arrow) at contact between Units II and III at Site U1352. Only two limestone pieces and some rubble were recovered. However, unconsolidated glauconitic sand may have been present originally, but it was injected into the overlying glauconitic marlstone and limestone to produce the observed layers (see also B), some of which cross cut primary stratigraphy and/or display branching. [B] Glauconitic limestone above the paraconformity. [C] and [D] Stylolitic white limestone (Amuri Limestone equivalent) below the paraconformity. [E] Muddy limestone with layers of marlstone and purple banding below the paraconformity. B-E are at the same vertical scale (from Fulthorpe et al., 2011). 
shallow-water settings, as has been done off New Jersey, Tahiti, and the Great Barrier Reef (IODP Expeditions 313, 310 , and 325 , respectively). Additional drilling of carbonate clinoforms is also required to evaluate how the response of such systems to sea-level change differs from that of siliciclastic systems. Finally, drilling on active margins should be explored to take advantage of very high rates of sediment supply that create expanded sections and allow study of eustatic cycles at orbital forcing frequencies, as well as illuminating the interplay of eustatic and tectonic forcing.

\section{Acknowledgements}

We thank the crew of the D/V JOIDES Resolution and all drilling operations personnel, who overcame the considerable difficulties associated with drilling deep boreholes in shallow water to ensure the success of Expedition 317. Many thanks are also due to the U.S. Implementing Organization technicians who are such a vital part of the drilling program. The authors also thank three anonymous reviewers for their helpful and insightful input.

\section{IODP Expedition 317 Scientists}

Craig Fulthorpe (Co-Chief Scientist), Koichi Hoyanagi (Co-Chief Scientist), Peter Blum (Staff Scientist), Stacie Blair, Gregory Browne, Robert Carter, Maria-Cristina Ciobanu, George Claypool, Martin Crundwell, Jaime Dinarès-Turrell, Xuan Ding, Simon George, Gilles Guèrin, Daniel Hepp, John Jaeger, Shungo Kawagata, David Kemp, Young-Gyun Kim, Michelle Kominz, Helen Lever, Julius Lipp, Kathleen Marsaglia, Cecilia McHugh, Naomi Murakoshi, Takeshi Ohi, Laura Pea, Julie Pollard, Mathieu Richaud, Angela Slagle, Itsuki Suto, Susumu Tanabe, Kirsteen Tinto, Goichiro Uramoto, and Toshihiro Yoshimura

\section{References}

Abbott, S.T., and Carter, R.M., 1999. Stratigraphy of the Castlecliffian type section: Ten mid-Pleistocene sequences from the Wanganui coast, New Zeal. J. Geol. Geop., 42:91-111, doi:10. 1080/00288306.1999.9514834.

Abbott, S.T., Naish, T.R., Carter, R.M., and Pillans, B.J., 2005. Sequence stratigraphy of the Nukumaru stratotype (Pliocene-Pleistocene, c. 2.08-1.63 Ma) Wanganui Basin, New Zealand. J. Roy. Soc. New Zeal., 35:123-150, doi:10.108 0/03014223.2005.9517779.

Adams, C.J.D., 1979. Age and origin of the Southern Alps. In Walcott, R.I., and Cresswell, M.M. (Eds.), The Origin of the Southern Alps, Royal Society of New Zealand Bulletin, 18:73-78.

Austin, J.A., Jr., Christie-Blick, N., Malone, M.J., Mountain, G.S., and the Leg 174A Shipboard Party, 1998. Proc. ODP, Init. Repts., 174A: College Station, TX (Ocean Drilling Program).

Batt, G.E., Braun, J., Kohn, B.P., and McDougall, I., 2000. Thermochronological analysis of the dynamics of the Southern Alps, New Zealand. Geol. Soc. Am. Bull., 112:250-266, doi:10.1130/0016-7606(2000)112<250:TAOT
$\mathrm{DO}>2.0 . \mathrm{CO} ; 2$.

Carter, L., Carter, R.M., McCave, N.I., and Gamble, J., 1996. Regional sediment recycling in the abyssal Southwest Pacific Ocean. Geology, 24:735-738, doi:10.1130/0091-7613(1996)024< 0735:RSRITA $>2.3$. CO;2.

Carter, R.M., 1985. The mid-Oligocene Marshall Paraconformity, New Zealand: Coincidence with global eustatic fall or rise? J. Geol., 93:359-371, doi:10.1086/628957.

Carter, R.M., and Landis, C.A., 1972. Correlative Oligocene unconformities in southern Australasia. Nature, 237:12-13.

Carter, R.M., and Norris, R.J., 1976. Cainozoic history of southern New Zealand: An accord between geological observations and plate-tectonic predictions. Earth Planet. Sci. Lett., 31:85-94, doi:10.1016/0012-821X(76)90099-6.

Carter, R.M., Abbott, S.T., Fulthorpe, C.S., Haywick, D.W., and Henderson, R.A., 1991. Application of global sea-level and sequence stratigraphic models in southern hemisphere Neogene strata from New Zealand. In MacDonald, D. (Ed.), Sea-level and Active Plate Margins. International Association of Sedimentologists Spec. Pub., 12:41-65.

Carter, R.M., McCave, I.N., and Carter, L., 2004. Leg 181 synthesis: Fronts, flows, drifts, volcanoes, and the evolution of the southwestern gateway to the Pacific Ocean, Eastern New Zealand. In Richter, C. (Ed.), Proc. ODP Scientific Results, 181, College Station, TX (Ocean Drilling Program), 1-111.

Chiswell, S.M., 1996. Variability in the Southland Current, New Zealand. New Zeal. J. Mar. Fresh. Res., 30:1-17, doi:10.1080/ 00288330.1996 .9516693$.

Christie-Blick, N., 1991. Onlap, offlap, and the origin of unconformitybounded depositional sequences. Mar. Geol., 97:35-56, doi:10.1016/0025-3227(91)90018-Y.

Field, B.D., and Browne, G.H., 1989. Cretaceous and Cenozoic sedimentary basins and geological evolution of the Canterbury Region, South Island, New Zealand. New Zeal. Geol. Surv. Bull., 2, 94 p.

Fleming, C.A., 1962. New Zealand biogeography: A paleontologist's approach. Tuatara, 10:53-108.

Fulthorpe, C.S., and Carter, R.M., 1991. Continental shelf progradation by sediment drift accretion. Geol. Soc. Am,. Bull., 103:300-309, doi:10.1130/0016-7606(1991)103<0300:CSPB $\mathrm{SD}>2.3 . \mathrm{CO} ; 2$.

Fulthorpe, C.S., Carter, R.M., Miller, K.G., and Wilson, J., 1996. Marshall Paraconformity: A mid-Oligocene record of inception of the Antarctic Circumpolar Current and coeval glacioeustatic lowstand? Mar. Petrol. Geol., 13:61-77, doi:10.1016/0264-8172(95)00033-X.

Fulthorpe, C.S., Hoyanagi, K., Blum, P., and the Expedition 317 Scientists, 2011. Proc. IODP, 317: Tokyo (Integrated Ocean Drilling Program Management International, Inc.), doi:10.2204/iodp.proc.317.2011.

Haq, B.U., Hardenbol, J., and Vail, P.R., 1987. Chronology of fluctuating sea levels since the Triassic. Science, 235:1156-1167, doi:10.1126/science.235.4793.1156.

Kamp, P.J.J., 1987. Age and origin of the New Zealand orocline in relation to Alpine Fault movement. J. Geol. Soc. London, 144:641-652, doi:10.1144/gsjgs.144.4.0641.

Karner, G.D., 1986. Effects of lithospheric in-plane stress on sedimentary basin stratigraphy. Tectonics, 5:573-588, doi:10.1029/ TC005i004p00573. 
King, P.R., 2000. Tectonic reconstructions of New Zealand: 40 Ma to the Present. New Zeal. J. Geol. Geop., 43:611-638, doi:10.108 0/00288306.2000.9514913.

Kominz, M.A., Browning, J.V., Miller, K.G., Sugarman, P.J., Mizintseva, S., and Scotese, C.R., 2008. Late Cretaceous to Miocene sea-level estimates from the New Jersey and Delaware coastal plain coreholes: An error analysis. Basin Res., 20:211-226, doi:10.1111/j.1365-2117.2008.00354.x.

Lu, H., and Fulthorpe, C.S., 2004. Controls on sequence stratigraphy of a middle-Miocene to Recent, current-swept, passive margin: Offshore Canterbury Basin, New Zealand. Geol. Soc. Am. Bull., 116:1345-1366, doi:10.1130/B2525401.1.

Lu, H., Fulthorpe, C.S., and Mann, P., 2003. Three-dimensional architecture of shelf-building sediment drifts in the offshore Canterbury Basin, New Zealand. Mar. Geol., 193:19-47, doi:10.1016/S0025-3227(02)00612-6.

Lu, H., Fulthorpe, C.S., Mann, P., and Kominz, M., 2005. MioceneRecent tectonic controls on sediment supply and sequence stratigraphy: Canterbury Basin, New Zealand. Basin Res., 17:311-328, doi:10.1111/j.1365-2117.2005.00266.x.

Miall, A.D, and Miall, C.E., 2001. Sequence stratigraphy as a scientific enterprise: The evolution and persistence of conflicting paradigms. Earth Sci. Rev. 54:321-348, doi:10.1016/ S0012-8252(00)00041-6.

Miller, K.G., Kominz, M.A., Browning, J.V., Wright, J.D., Mountain, G.S., Katz, M.E., Sugarman, P.J., Cramer, B.S., ChristieBlick, N., and Pekar, S.F., 2005. The Phanerozoic record of global sea-level change. Science, 310:1293-1298, doi:10.1126/science.1116412.

Mitchum, R.M., Vail, P.R., and Thompson, S., 1977. Seismic stratigraphy and global changes of sea level, part 2: The depositional sequence as a basic unit for stratigraphic analysis. In Payton, C.E. (Ed.), Seismic Stratigraphy - Applications to Hydrocarbon Exploration, AAPG Memoir, 26:53-62.

Morris, M., Stanton, B., and Neil, H., 2001. Subantarctic oceanography around New Zealand: Preliminary results from an ongoing survey. New Zeal. J. Mar. Fresh. Res., 35:499-519, doi:10 $.1080 / 00288330.2001 .9517018$.

Mountain, G., Proust, J.-N., and the Expedition 313 Science Party, 2010. The New Jersey margin scientific drilling project (IODP Expedition 313): Untangling the record of global and local sea-level changes. Sci. Drill., 10:26-34, doi:10.2204/ iodp.sd.10.03.2010.

Naish, T.M., Wehland, F., Wilson, G.S., Browne, G.H., Cook, R.A., Morgans, H.E., Rosenberg, M., King, P.R., Smale, D., Nelson, C.S., Kamp, P.J.J., and Ricketts, B., 2005. An integrated sequence stratigraphic, paleonenvironmental, and chronostratigraphic analysis of the Tangahoe Formation, southern Taranaki coast, with implications for mid-Pliocene (c. 3.4-3.0 Ma) glacio-eustatic sea-level changes. J. Roy. Soc. New Zeal., 35:151-196, doi:10.1080/03014223.2005.9517780.

Norris, R.J., Carter, R.M., and Turnbull, I.M., 1978. Cainozoic sedimentation in basins adjacent to a major continental transform boundary in southern New Zealand. J. Geol. Soc. London, 135:191-205, doi:10.1144/gsjgs.135.2.0191.

Saul, G., Naish, T.R., Abbott, S.T., and Carter, R.M., 1999. Sedimentary cyclicity in the marine Plio-Pleistocene of Wanganui Basin (N.Z.): Sequence stratigraphic motifs characteristic of the last 2.5 Ma. Geol. Soc. Am. Bull., 111:524-537, doi:10.1130/0016-7606(1999)111<0524:SCITMP>2.3.CO;2.
Shipboard Scientific Party, 1999. Leg 181 summary: Southwest Pacific paleoceanography. In Carter, R.M., McCave, I.N., Richter, C., Carter, L., et al., Proc. ODP Init. Repts., 181, College Station, TX (Ocean Drilling Program), 1-80.

Tippett, J.M., and Kamp, P.J.J., 1993a. Fission track analysis of the Late Cenozoic vertical kinematics of continental Pacific crust, South Island, New Zealand. J. Geophys. Res., 98:1611916148, doi:10.1029/92JB02115.

Tippett, J.M., and Kamp, P.J.J., 1993b. The role of faulting in rock uplift in the Southern Alps, New Zealand. New Zeal. J. Geol. Geop. 36:497-504, doi:10.1080/00288306.1993.9514595.

Vail, P.R., Audemard, F., Bowman, S.A., Eisner, P.N., and Perez-Cruz, C., 1991. The stratigraphic signatures of tectonics, eustasy and sedimentology—an overview. In Einsele, G., Ricken, W., and Seilacher, A. (Eds.), Cycles and Events in Stratigraphy: Berlin (Springer-Verlag), 617-659.

Wellman, H.W., 1971. Age of the Alpine Fault, New Zealand. Proc. 22nd Int. Geol. Congr., 4:148-162.

\section{Authors}

Craig S. Fulthorpe, Institute for Geophysics, John A. and Katherine G. Jackson School of Geosciences, University of Texas at Austin, 10100 Burnet Road (R2200), Building 196 (ROC), Austin, TX 78758-4445, U.S.A., E-mail: craig@ig. utexas.edu.

Koichi Hoyanagi, Department of Geology, Faculty of Science, Shinshu University, 3-1-1 Asahi, Matsumoto 3908621, Japan, E-mail: hoya101@shinshu-u.ac.jp.

Peter Blum, United States Implementing Organization, Integrated Ocean Drilling Program, Texas A\&M University, 1000 Discovery Drive, College Station, TX 77845, U.S.A., E-mail: blum@iodp.tamu.edu.

and the IODP Expedition 317 Scientists 